\title{
Prediksi rating reksadana berbasis algoritma decision tree pada sistem informasi reksadana
}

\section{Kartika Candra Kirana ${ }^{1}$, Cahya Bintang Wira Winata ${ }^{2}$, Indri Astuti ${ }^{3}$, Ivan Reynaldi Putra ${ }^{4}$}

1. Universitas Negeri Malang, Indonesia | kartika.candra.ft@um.ac.id

2. Universitas Negeri Malang, Indonesia | ataniwariw@yahoo.co.id

3. Universitas Negeri Malang, Indonesia | i.liszto@gmail.com

4. Universitas Negeri Malang, Indonesia | ivanrputra@gmail.com

\begin{abstract}
Abstrak
Informasi yang terdapat pada situs reksadana pada saat ini hanya menampilkan tetang variabel reksadana saja secara umum seperti nilai NAV, RAB, Resiko, YTD, dan lainya, sehingga para investor yang masih baru dalam reksadana akan kesulitan dalam menentukan pilihan reksadaana yang akan dibeli. Oleh karena itu pada penelitian ini diusulkan prediksi rating reksadana berbasis algoritma decision tree pada sistem informasi reksadana dengan tujuan untuk menampilkan sebuah variabel rating sebagai bahan pertimbangan dan meningkatkan keakuratan dalam memberikan rating pada penelitian prediksi rating reksadana. Algoritma yang digunakan dalam pembuatan sistem informasi prediksi rating reksadana ini adalah menggunakan algoritma decision tree dengan menggunakan variabel NAV, HILO, Resiko, dan YTD. Pengujian akurasi, spesifikasi, dan sensitivity dilakukan menggunakan data yang sudah diunduh pada website reksadana IPOTFUND. Jumlah data yang digunakan yaitu 50 data, yang terdiri dari 25 data latih dan 25 data uji. Dari hasil pengujian yang dilakukan dengan metode decision tree maka menunjukkan tingkat akurasi, spesificity, dan sensitivity sebesar $80 \%$, 93\%, dan $67 \%$. Maka dapat disimpulkan bahwa algoritma decision tree bekerja secara akurat untuk pemberian rating reksa dana.
\end{abstract}

\section{Kata Kunci}

Decision tree, Reksadana, Decision support system, information system 


\section{TEKNO Jurnal Teknologi Elektro dan Kejuruan}

http://journal2.um.ac.id/index.php/tekno | 1693-8739 / 2686-4657

\section{Pendahuluan}

Investasi reksa dana pada saat ini sudah banyak berkembang pada masyarakat, banyak masyarakat awam yang telah menyadari perlunya berinfestasi reksa dana. Selain itu, peningkatan jumlah kesibukan manusia urban juga menjadi factor penyebab rendahnya minat investasi(Tandio and Widanaputra, 2016; Aco and Endang, 2017). Pengembangan system informasi menjadi solusi usaha dalam meningkatkan minat masyarakat dalam berinvestasi. Namun banyak website yang menampilkan sistem informasi yang seadanya (Dita Larasati, Bimo Setyo Yuusufa, 2015), sehingga para calon investor merasa kebingungan dalam mempelajari cara untuk berinvestasi tentang reksa dana.

Salah satu faktor yang membuat ragu calon infestor baru yaitu mereka mengalami kesulitan dalam memilih reksa dana yang baik. Mereka juga masih belum mengerti keriteria seperti apa yang menandakan bahwa reksa dana tersebut memang baik sehingga dipelukan variabel rating sebagai saran dari website reksa dana untuk menilai. Oleh karena itu, diperlukan sebuah otomatiasasi prediksi rating di dalam sebuah sistem informasi reksa dana untuk mempermudah dalam pengambilan keputusan para calon investor untuk memilih reksa dana yang akan di infestasikan. Pengambilan keputusan seharusnya berdasarkan analisa produk Reksa Dana. Beberapa indikator analisa yang dapat digunakan antara lain: jenis manajer Investasi (Ardianto, 2014) dan instrument pendukungnya (FEBRIANI, DARMINTO and HUSAINI, 2014).

Beberapa penelitian telah mengembangkan instumen pendukung pemilihan reksadana. Salah satu algoritma yang dikembangkan adalah optimal portofolio reksa dana saham menggunakan algoritma genetika multi-objective (Yusuf, Arkeman and Mushthofa, 2012; Sofariah, Saepudin and Umbara, 2016) Metode yang digunakan dalam penelitian ini menggunakan teknik Multi-algoritma genetika. Dari hasil analisis, akan didapat portofolio yang terbaik dari beberapa reksadana. Selain itu, teknik Multi-Objective Genetic Algorithm NonDominated Sorting II (MOGA NSGA-II) juga telah diterapkan sebagai bentuk optimasi fitur reksadana (Arkeman, Yandra; Yusuf, Akhmad; Mushthofa; FitriLaxmi, Gibtha; Seminar, 2013). Dari hasil analisis, terbentuk tiga cluster yang dapat dijadikan rekomendasi investasi berdasarkan tingkat keuntungan / risiko, yaitu pada cluster pertama termasuk investasi dengan tingkat keuntungan / risiko menengah. Cluster kedua termasuk investasi dengan tingkat keuntungan / risiko yang rendah. Cluster ketiga termasuk investasi tingkat keuntungan / risiko tinggi. Ketiga cluster tersebut dapat digunakan sebagai rekomendasi berinvestasi pada Reksa Dana dengan memertimbangkan keuntungan yang akan dicapai dan kemungkinan resiko yang dapat terjadi. Hereil dkk (2010) juga telah menggunakan teknik pemodelan Markov dari pemberian rating. Dari hasil analisis, didapat bahwa sistem rating tidak perlu waktu yang sama, dan pentingnya gaya sangat penting ketika membandingkan peringkat reksa dana (Hereil et al., 2010).

Disisi lain, penawaran produk reksadana tidak hanya didasarkan pada sudut pandang produk, tetapi juga investor sebagai pengguna produk investasi. Pengelompokan komersialitas investor pada penawaran produk investasi seperti reksadana dan saham juga telah 


\section{TEKNO Jurnal Teknologi Elektro dan Kejuruan}

http://journal2.um.ac.id/index.php/tekno | 1693-8739 / 2686-4657

dikembangkan menggunakan algoritma K-Means(Kristanto., L.A and S., 2016). Metode ini menerapkan pembaruan rata-rata kelompok komersial dan tidak komersial sebagai penentu perusahaan dalam menawarkan produk inverstasi. Bagaimanapun kelemahan penelitian ini adalah tidak memberikan rekomendasi bagi kalangan investor komersial investasi apa yang cocok dibeli berdasarkan karakteristik pelangan. Dari beberapa penelitian ditemukan bahwa salah satu kekurangan penggunaan algoritma genetika yaitu karena semua komponen Algoritma Genetika bersifat random atau acak mengakibatkan solusi yang dihasilkan berbedabeda pada setiap kali dijalankan. Tetapi kejadian ini dapat dihindari dengan memilih nilai-nilai parameter dengan tepat (Kusumadewi, 2003).

Salah satu metode yang dapat digunakan sebagai pengatur nilai yang tetap adalah decision tree. Decision tree mampu memetakan aturan dalam formasi pohon keputusan berdasarkan data latih. Formasi tersebut bernilai tetap jika data latih tidak berubah. Bagaimanapun, formasi pohon keputusan dapat berubah secara fleksibel jika terdapat perubahan data latih (Alpay, Abawi and Wermter, 2019). Selain itu, penggunaan decision tree mampu mengidentifikasi masalah dengan tingkat kesalahan terendah (Ahmed Mohamed Ahmed, Ahmet Rizaner, 2018). Lebih lanjut, pada kasus pemilihan saham, pohon keputusan dapat memetakan sesuai keinginan investor dengan bantuan regresi (Eric H. Sorensen, 2000). Pembaharuan metode decision tree juga terus digalakkan untuk optimasi perfoma system, seperti decision tree 5.0 (Qiansheng Zhang, Jingru Zhang, Zisheng Chen, Miao Zhang, 2018). Beberapa penelitian juga mengkombinasi Decision tree juga dapat dikombinasi dengan metode lain seperti HMM untuk memprediksi tren saham (Tiwari, Pandit and Richhariya, 2018). Dengan mempertimbangkan keunggulan decision tree mempelajari data latih tanpa melibatkan nilai random, metode ini diharapkan memberi kepastian prioritas rating reksadana secara akurat. Metode yang diusulkan adalah ID3 sebagai mode decision tree learning yang paling dasar. Algoritma ini melakukan pencarian secara menyeluruh pada semua kemungkinan pohon keputusan, sehingga rating yang dihasilkan merupakan nilai analisa yang kompleks.

Untuk itu, penelitian ini diusulkan "Prediksi Rating Reksadana Berbasis Algoritma Decision Tree pada Sistem Informasi Reksadana" dengan memanfaatkan website reksadana IPOTFUND yang digunakan sebagai dasar dalam pembuatan algoritma untuk mencari nilai rating dari variabel Nav, Ytd, Hilo, dan Resiko. Dan selanjutnya akan digunakan untuk memberi rating pada website lain untuk dapat memberikan variabel rating sehingga akan membantu para calon investor. Tujuan dari penelitian ini adalah meningkatkan keakuratan dalam memberikan rating pada penelitian prediksi rating reksadana. Dengan menggunakan algoritma decision tree sebagai algoritma pemberian rating dari reksadana

\section{METODE}

\subsection{Data Penelitian}

Sumber data yang digunakan pada penelitian ini diperoleh dari website reksa dana IPOTFUND yang diakses pada bulan maret 2016. Dalam sistem prediksi rating reksa dana

TEKNO Vol. 29 Issue 2, p140-151 | Jurusan Teknik Elektro, Universitas Negeri Malang, Indonesia | September 2019

K. C. Kirana, C. B. W. Winata, I. Astuti, I. R. Putra | Prediksi rating reksadana berbasis algoritma decision tree... 


\section{TEKNO Jumal Teknologi Elekrio dan Kejivruan}

http://journal2.um.ac.id/index.php/tekno | 1693-8739 / 2686-4657

dibutuhkan data latih dan data uji. Data latih sebagai dasar perbandingan dengan data uji dengan variabel yang sudah ditentukan. Total data untuk penelitian ini yaitu 50 data, yang terdiri dari 25 data merupakan data latih dan 25 data sisanya sebagai data uji.

Dalam penelitian ini digunakan empat buah variabel dalam menentukan rating. Variabel tersebut yaitu NAV (Net Asset Value), YTD (Year To Date), HILO dan Resiko.

\subsection{Pengembangan Prediksi Rating Reksa Dana Berbasis Algoritma Decision Tree}

Secara umum, decision tree memuat 3 jenis node, yaitu: (1) root node yang merupakan node paling atas yang tidak ada input dan bisa tidak mempunyai output atau mempunyai output lebih dari satu, (2) internal node yang merupakan node percabangan, pada node ini hanya terdapat satu input dan mempunyai output minimal dua, dan Leaf node atau terminal node yang merupakan node akhir, pada node ini hanya terdapat satu input dan tidak mempunyai output.

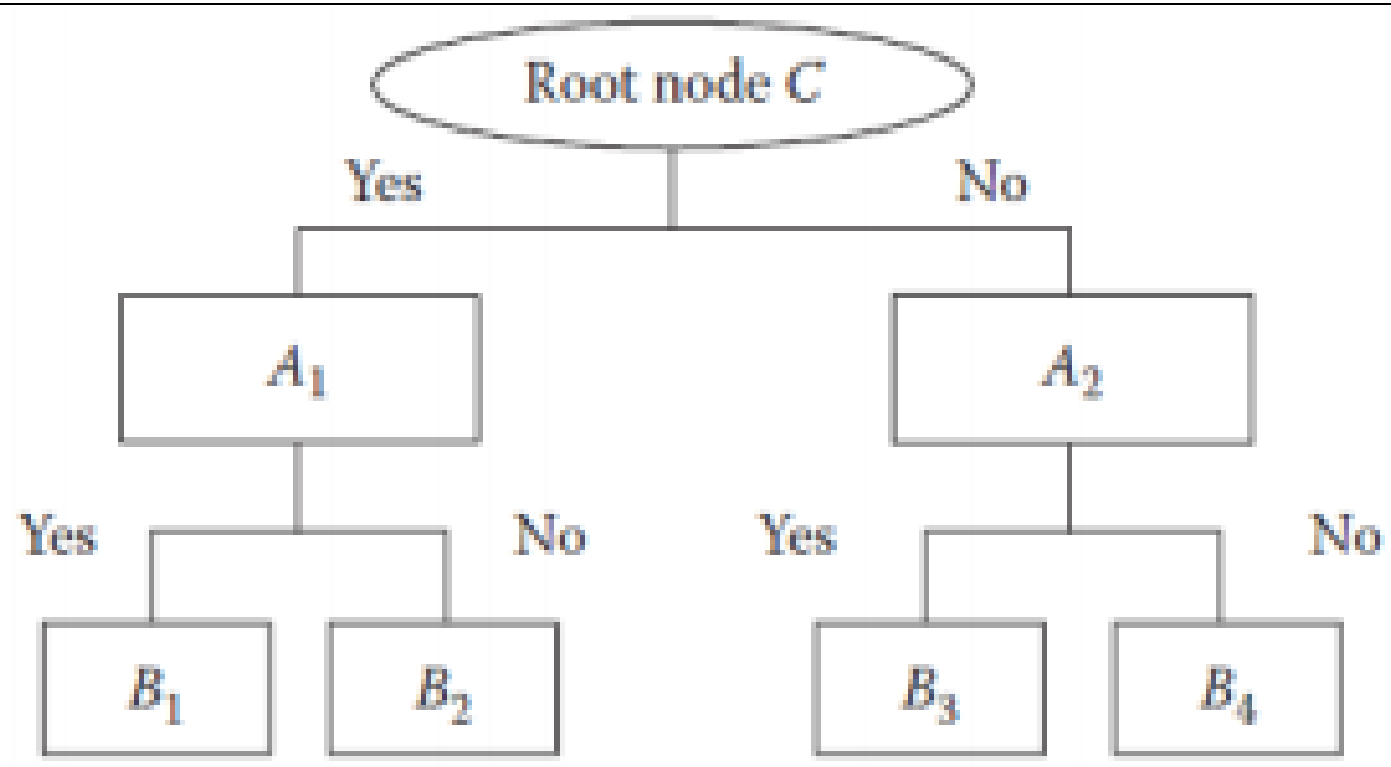

Gambar 1. Contoh Struktur Decision Tree

Seperti ditunjukkan dalam Gambar 1, decision tree tergantung pada aturan if-then, tetapi tidak membutuhkan parameter dan metrik. Struktur sederhana dan dapat ditafsirkan memungkinkan decision tree untuk memecahkan masalah atribut multi-type.

Pada penelitian ini menerapkan algoritma Decision Tree. Adapun pseudocode algoritma ditunjukkan pada Gambar 2. 


\section{TEKNO Junal Teknologi Elekrto dan Kejuruan}

http://journal2.um.ac.id/index.php/tekno | 1693-8739 / 2686-4657

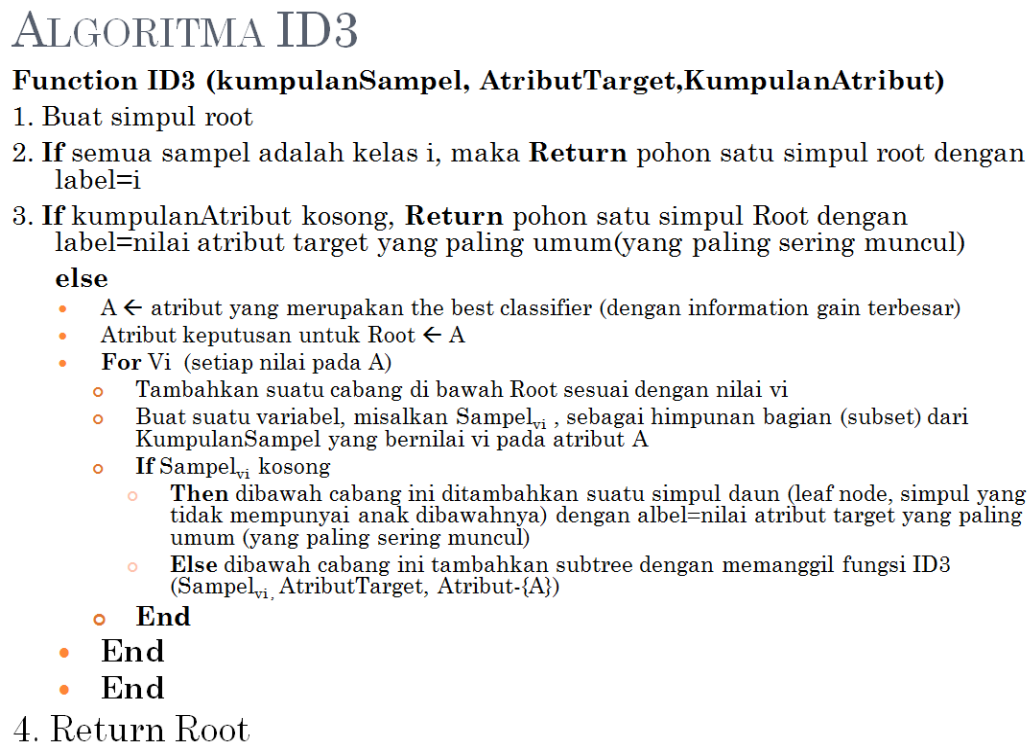

Gambar 2. Pseudocode Decision Tree ID3

Berdasarkan Gambar 2, tahap pertama algoritma Decision Tree adalah mencari dan menginputkan dataset yang sesuai dengan variabel yang telah dirancang. Kemudian nilai Entropi sampel (dari semua dataset) dicari dengan Persamaan 1,

Entropy $(\mathrm{S})=\sum_{\mathrm{i}}^{6}-\mathrm{p}_{\mathrm{i}} \log _{2} \mathrm{p}_{\mathrm{i}}$

Pers.(1)

dimana S adalah entropy, c adalah nilai makasimu, i yaitu kelas, dan $\mathrm{p}$ adalah nilai probabilitas. Kemudian mencari nilai gain dari setiap variabel yang dipakai (NAV, YTD, HILO, dan Resiko) dengan Persamaan 2.

$\operatorname{Gain}(\mathrm{S}, \mathrm{A})=\operatorname{Entropy}(\mathrm{S})-\sum_{\text {veValues }(A)} \frac{\left|\mathrm{S}_{\mathrm{v}}\right|}{\mathrm{S}} \operatorname{Entropy}\left(\mathrm{S}_{\mathrm{v}}\right)$

Pers.(2)

Dimana $A$ adalah atribut, $V$ menyatakan suatu nilai yang mungkin untuk atribut $A$, Values(A) yaitu himpunan nilai-nilai yang mungkin untuk atribut $A, \mid S v /$ adalah jumlah sampel untuk nilai $v, / S /$ adalah jumlah seluruh sampel data, Entropy(Sv) entropy untuk sampel-sampel yang memiliki nilai v. Lalu tahap ketiga adalah membuat rule dari dataset yang ada. Pada tahap 


\section{TEKNO Jumal Teknologi Elekrio dan Kejivruan}

http://journal2.um.ac.id/index.php/tekno | 1693-8739 / 2686-4657

terakhir hasil perhitungan gain dimasukkan kedalam rule yang ada sehingga rating muncul sesuai rule yang dibuat.

\subsection{Metode Pengujian}

Terdapat 3 metode pengujian yaitu sensitifity, specificity, dan akurasi. Perhitungan proses pengujian masing-masing ditunjukkan pada Persamaan 3, 4, dan 5.

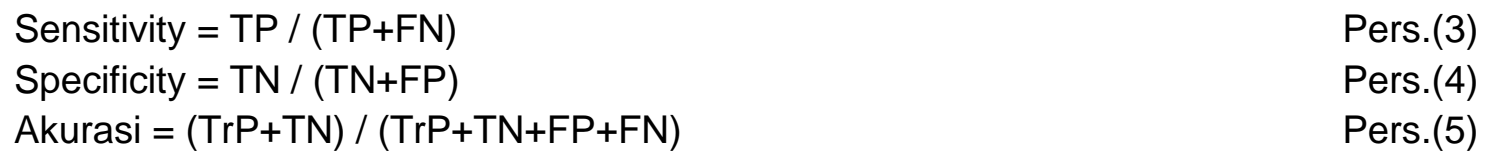

Pada Persamaan 3, 4 dan 5, TP merupakan True Positive, bagian yang seharusnya diklasifikasikan dalam suatu rating (misal A), dan memang dikenali sebagai rating A. FP adalah False Positive, bagian yang seharusnya tidak diklasifikasikan dalam rating $A$, akan tetapi dikenali sebagai rating $A$. TN adalah True Negative, bagian yang seharusnya dikenali sebagai selain rating $A$, dan memang dikenali sebagai selain rating $A$. $F N$ adalah False Negative, bagian yang seharusnya diklasifikasikan dalam rating $A$, akan tetapi tidak dikenali sebagai rating $A$.

\section{HASIL DAN PEMBAHASAN}

\subsection{Pengembangan Sistem prediksi rating di Dalam Sistem Informasi Reksa Dana}

Pada proses jual beli reksa dana, diawali dengan proses login oleh user, bila user belum memiliki akun maka harus melakukan pendaftaran akun. Halaman login dan daftar user ditunjukkan pada Gambar 3 dan Gambar 4.

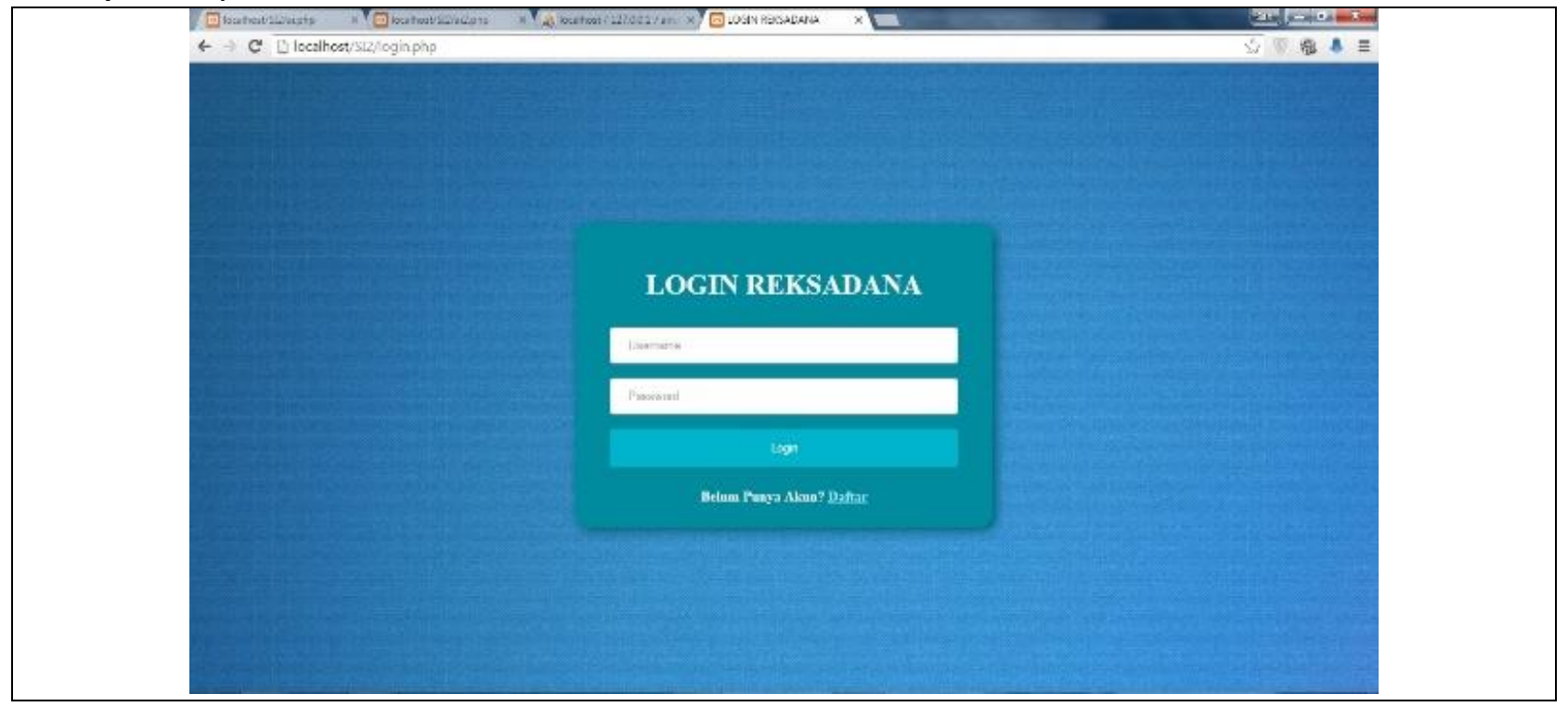

Gambar 3. Halaman Login user 


\section{TEKNO Jurnal Teknologi Elektro dan Kejuruan}

http://journal2.um.ac.id/index.php/tekno | 1693-8739 / 2686-4657

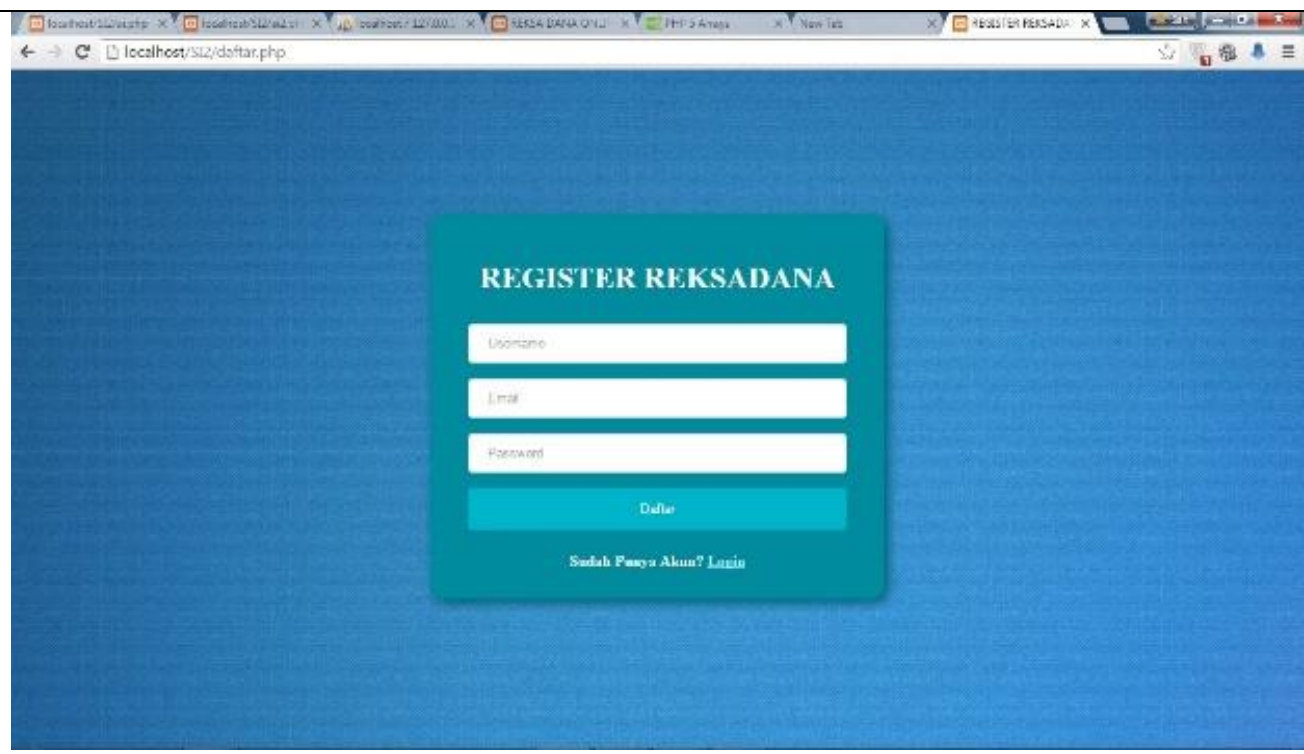

Gambar 4. Halaman daftar user

Selanjutnya user melakukan transaksi pembelian penjualan atau alih reksa dana. Halaman beli, jual, dan alih reksa dana ditunjukkan pada Gambar 5, Gambar 6, dan Gambar 7

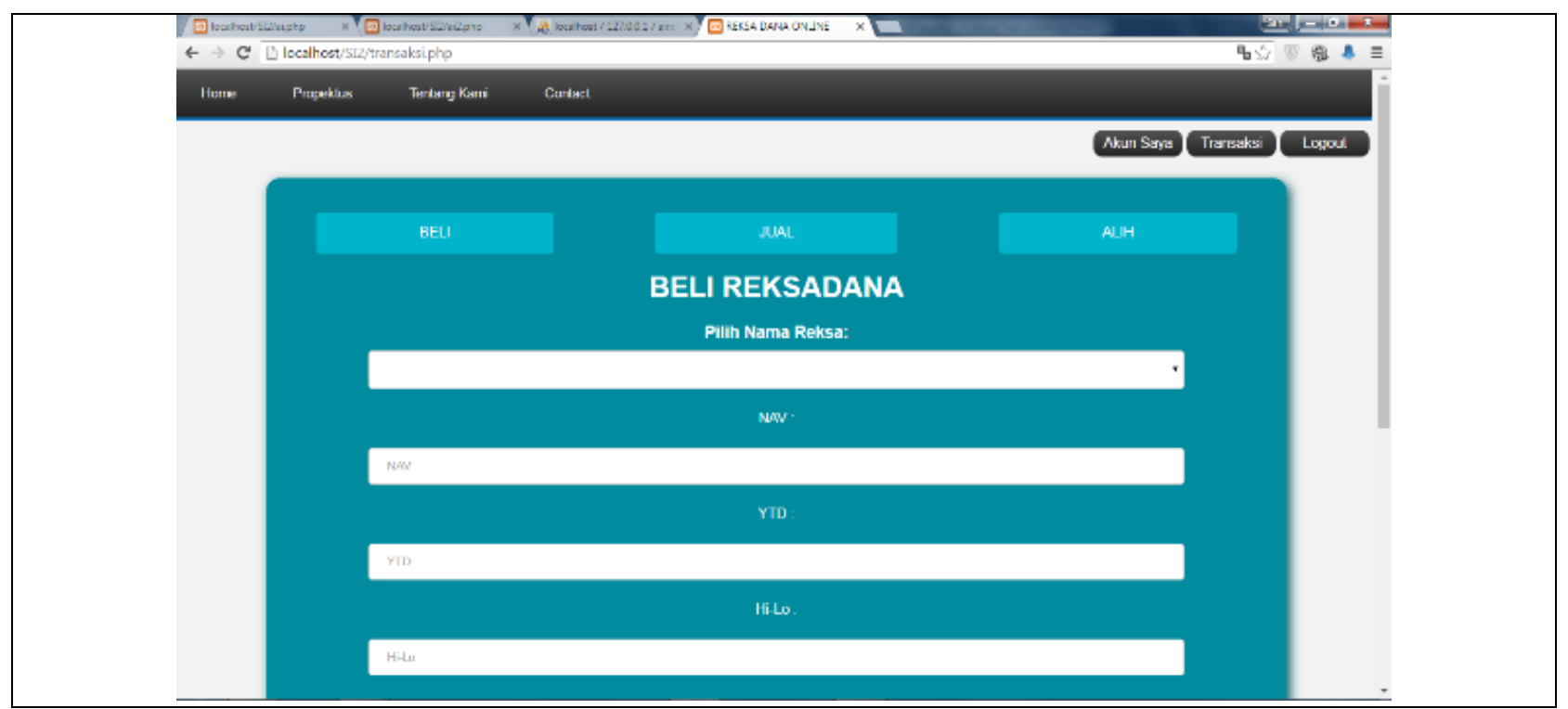

Gambar 5. Halaman beli user 


\section{TEKNO Jurnal Teknologi Elektro dan Kejuruan}

http://journal2.um.ac.id/index.php/tekno | 1693-8739 / 2686-4657

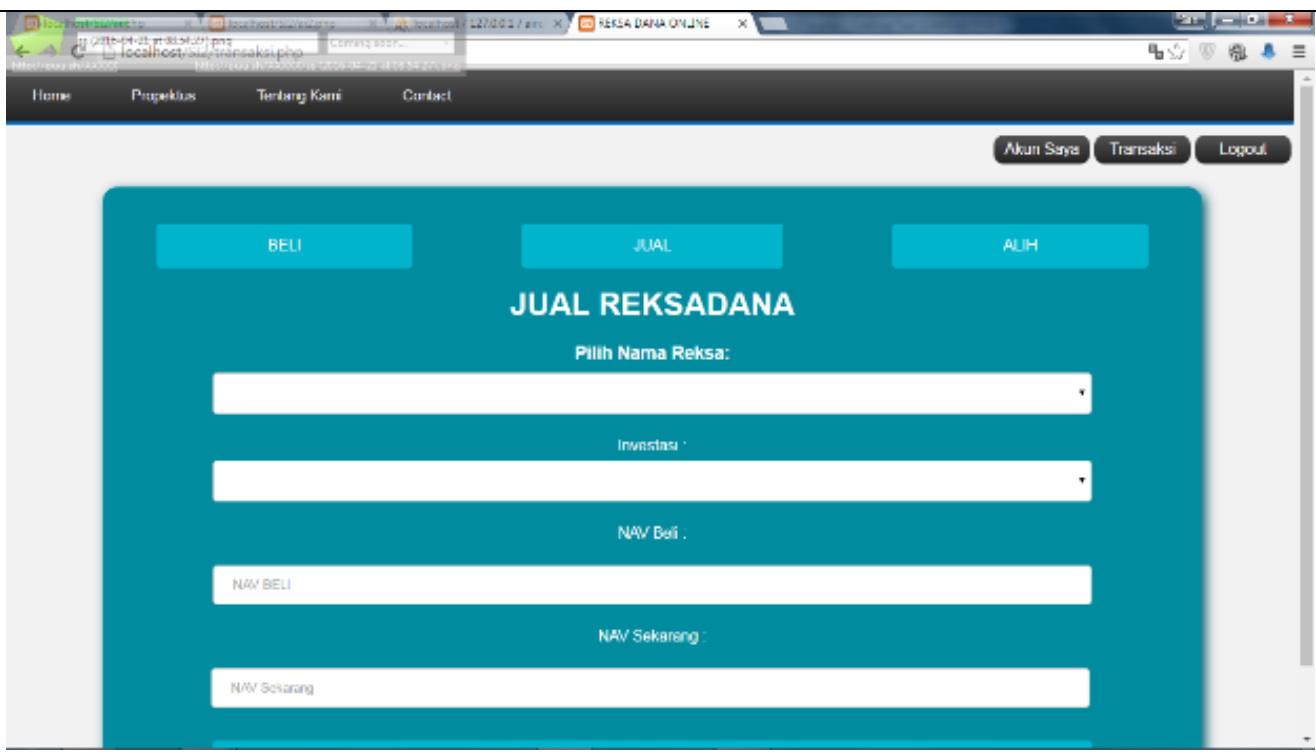

Gambar 6. Halaman jual user

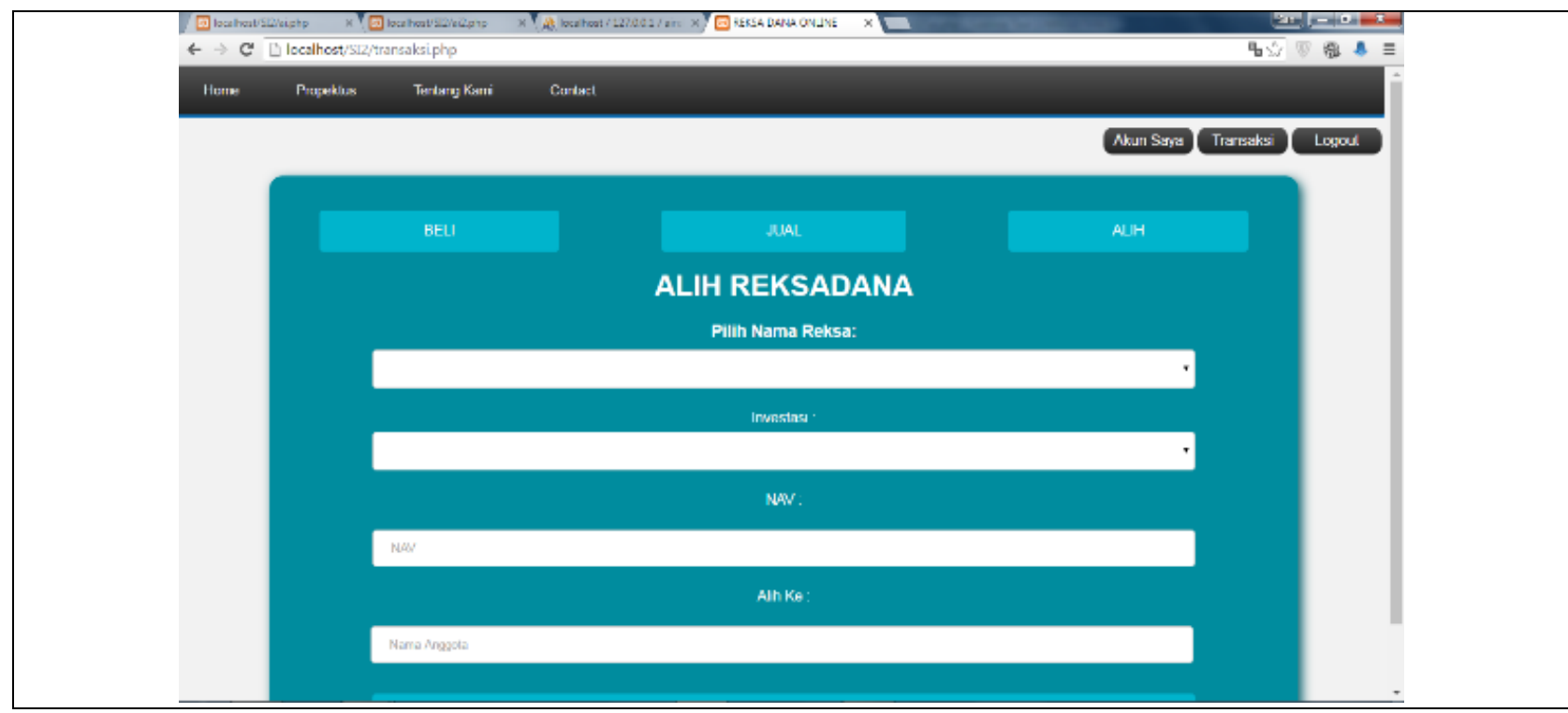

Gambar 7. Halaman alih user

Kemudian admin sebagai pengoperasi sistem informasi reksa dana. Halaman login admin ditunjukkan pada Gambar 8. 


\section{TEKNO Jurnal Teknologi Elektro dan Kejuruan}

http://journal2.um.ac.id/index.php/tekno | 1693-8739 / 2686-4657

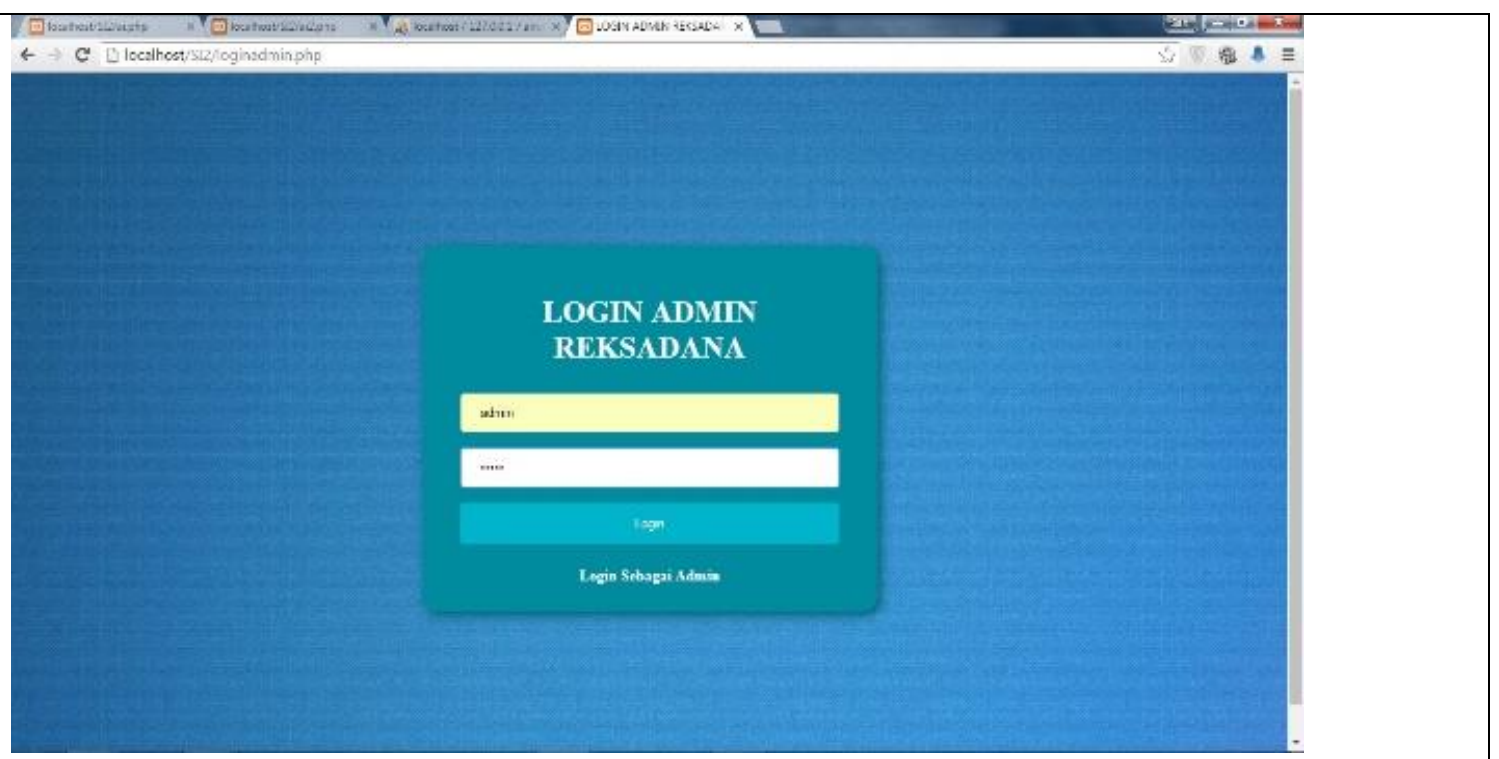

Gambar 8. Halaman Login Admin

Selanjutnya admin dapat memproses transaksi user dan juga memperbarui data reksa dana. Halaman pengajuan pinjaman dan update reksa dana ditunjukkan pada Gambar 9 dan Gambar 10.

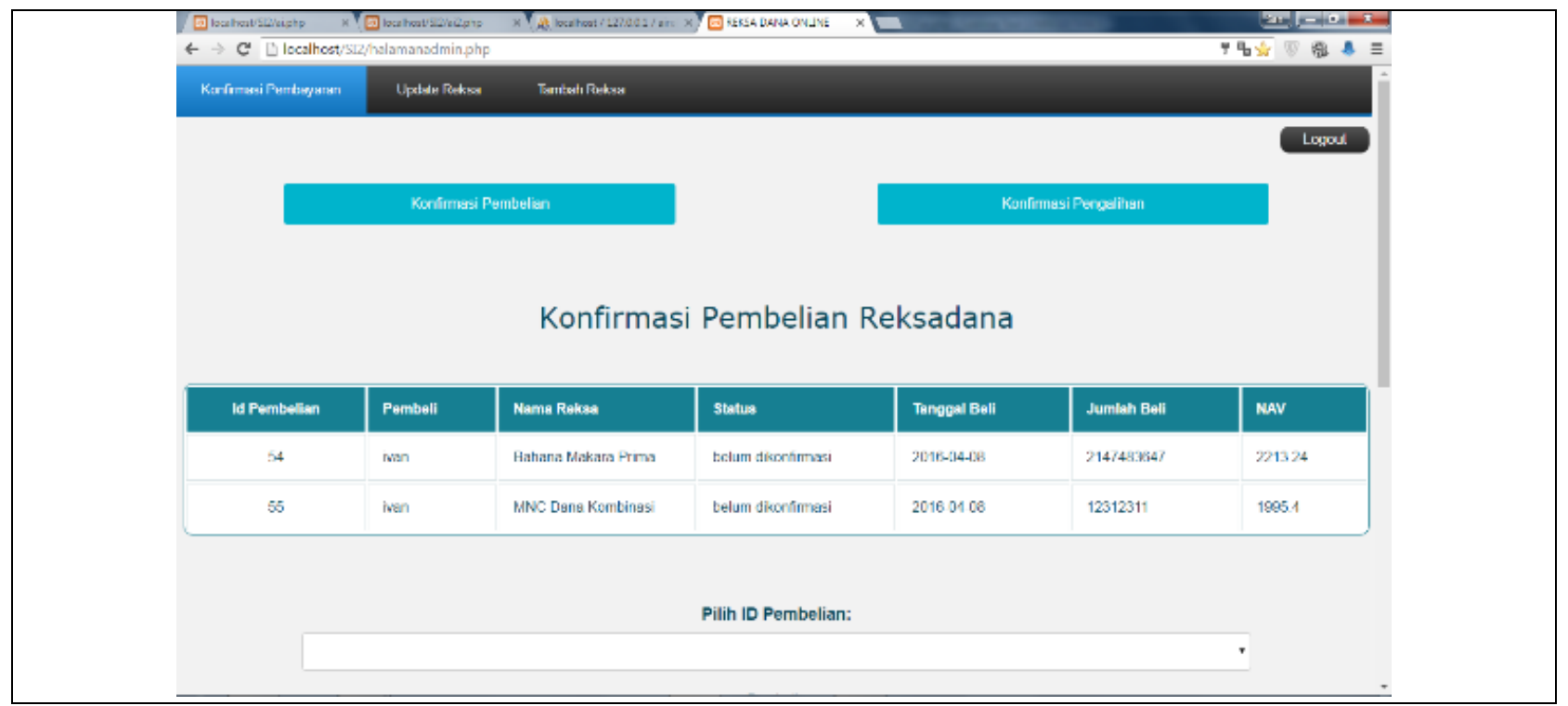

Gambar 9. Halaman konfirmasi Admin 


\section{TEKNO Jurnal Teknologi Elektro dan Kejuruan}

http://journal2.um.ac.id/index.php/tekno | 1693-8739 / 2686-4657

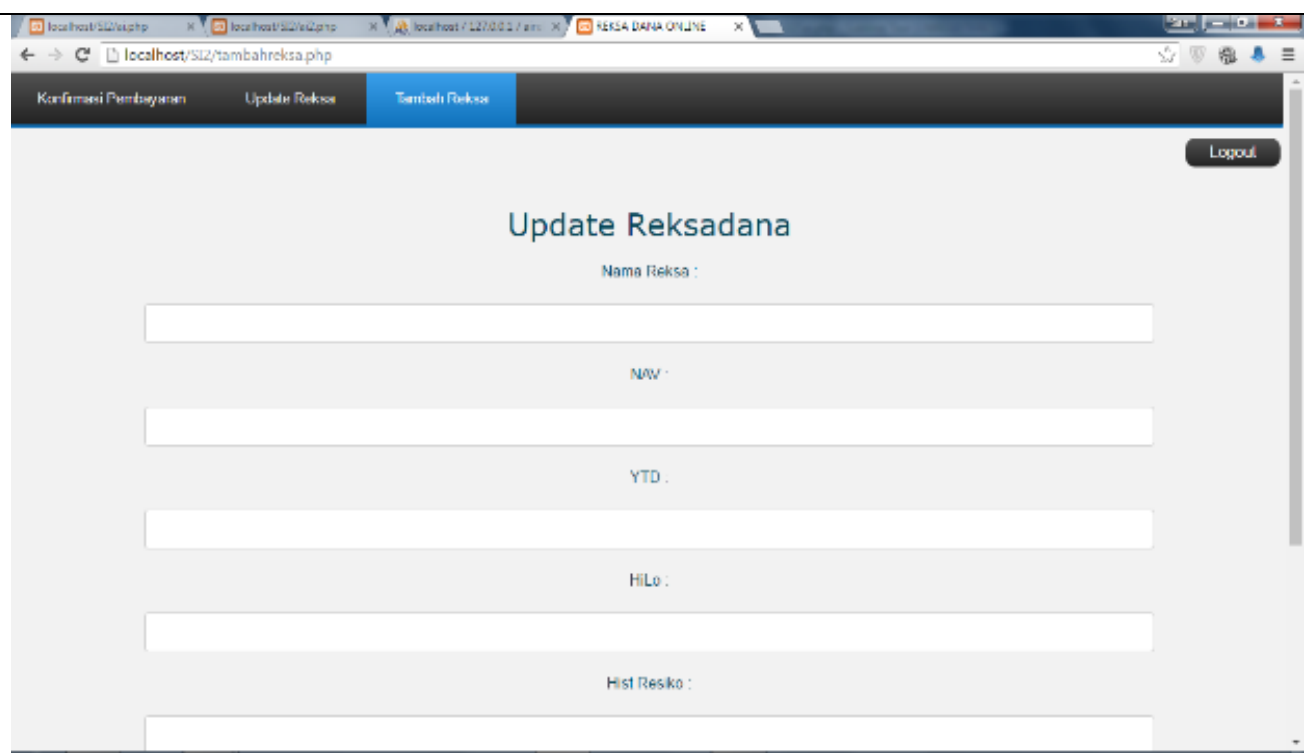

Gambar 10. Halaman update reksa dana Admin

\subsection{Pengujian Certainty Factor (CF) pada Sistem}

Deskripsi Prediksi Rating Reksa Dana Berbasis Decision Tree

Berikut adalah tampilan dari informasi rating pada sistem informasi jual beli Reksa Dana.

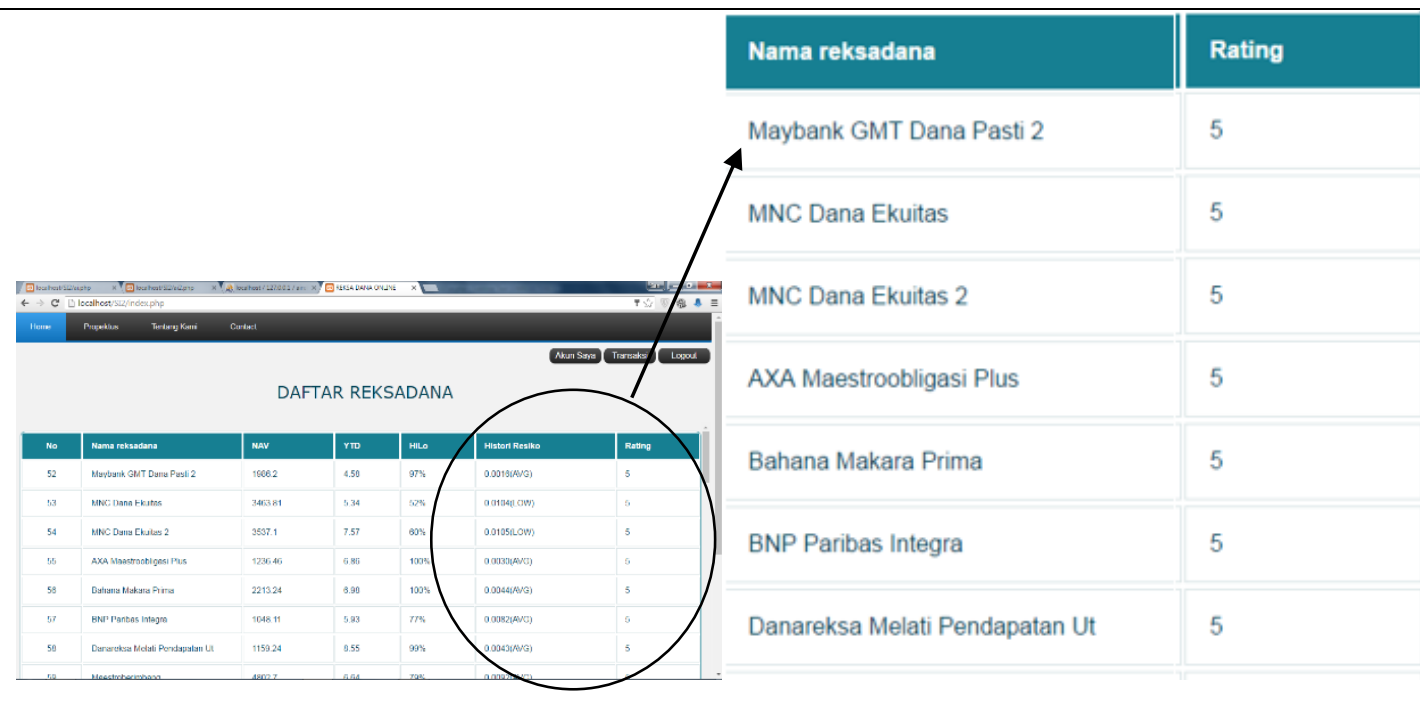

(a)

(b)

Gambar 11. Halaman rating reksa dana (a) Lama Rating (b) Detail Hasil Rating 


\section{TEKNO Jurnal Teknologi Elektro dan Kejuruan}

http://journal2.um.ac.id/index.php/tekno | 1693-8739 / 2686-4657

Dari tabel pengujian Tabel 1 diperoleh hasil terbaik yakni Sensitivity sebesar 53,33\%, Specificity sebesar $55,45 \%$ dan Akurasi sebesar $76 \%$. Bagimanapun akurasi yang tidak mencapai $100 \%$. Hal ini dimungkinkan karena data latih yang digunakan terlalu sedikit dan perhitungan rating reksa dana masih belum maksimal.

Tabel 1. Hasil Pengujian Sensitivity, Specificity, Akurasi

\begin{tabular}{cc}
\hline Pengujian & Nilai \\
\hline Sensitivity & $53,33 \%$ \\
Specificity & $55,45 \%$ \\
Akurasi & $76 \%$ \\
\hline
\end{tabular}

\section{KESIMPULAN}

Berdasarkan hasil uji coba prediksi rating menggunakan algoritma Decision Tree, menunjukkan yakni Sensitivity sebesar 53,33\%, Specificity sebesar 55,45\% dan Akurasi sebesar $76 \%$. Hal ini dapat disimpulkan bahwa peningkatan keakuratan prediksi rating reksa dana telah akurat untuk digunakan. walaupun hasil belum mencapai akurasi $100 \%$.

Kelemahan dari penelitian ini masih menggunakan variabel yang sedikit. Ada kemungkinan jika variabel bertambah maka sensitivity, specificity, dan akurasi akan lebih baik. Sehingga diharapkan pada penelitian selanjutnya dapat memperbaiki kelemahan yang ada.

\section{Daftar Rujukan}

Aco, A. and Endang, A. H. (2017) 'Analisis Bisnis E-Commerce pada Mahasiswa Universitas Islam Negeri Alauddin Makassar', Jurnal INSYPRO (Information System and Processing), 2(1), pp. 338-351. doi: 10.24252/insypro.v2i1.3246.

Ahmed Mohamed Ahmed, Ahmet Rizaner, A. H. U. (2018) 'A novel decision tree classification based on post-pruning with Bayes minimum risk', PLOS. doi: https://doi.org/10.1371/journal.pone.0194168.

Alpay, T., Abawi, F. and Wermter, S. (2019) 'Preserving activations in recurrent neural networks based on surprisal', Neurocomputing, 342, pp. 75-82. doi: https://doi.org/10.1016/j.neucom.2018.11.092.

Ardianto, E. (2014) Metode Penelitian Public Relation Kuantitatif dan kualitatif. Bandung: Remaja Rosdakarya.

Arkeman, Yandra; Yusuf, Akhmad; Mushthofa; FitriLaxmi, Gibtha; Seminar, K. B. (2013) 'The Formation of Optimal Portfolio of Mutual Shares Funds using Multi-Objective Genetic Algorithm', Telkomnika, 11(3), pp. 625-636. Available at: https://search.proquest.com/openview/faa4a7e7ab440934d8bfdb2b3b8b8409/1 ?pqorigsite $=$ gscholar \&cbl=376296.

Dita Larasati, Bimo Setyo Yuusufa, K. C. K. (2015) 'SISTEM PENDUKUNG KEPUTUSAN PRODUKSI BERBASIS FUZZY PADA SISTEM INFORMASI JUAL BELI MOBIL BEKAS', TEKNO, 24(2). Available at: http://journal.um.ac.id/index.php/tekno/article/view/5165.

Eric H. Sorensen, K. L. M. and C. K. O. (2000) 'The Decision Tree Approach to Stock Selection', The Journal of Portfolio Management Fall, 27(1), pp. 42-52. doi: 


\section{TEKNO Jurnal Teknologi Elektro dan Kejuruan}

http://journal2.um.ac.id/index.php/tekno | 1693-8739 / 2686-4657

https://doi.org/10.3905/jpm.2000.319781.

FEBRIANI, S., DARMINTO and HUSAINI, A. (2014) 'ANALISIS INVESTASI DALAM INSTRUMEN REKSADANA PADA DANA PENSIUN (Studi Pada Dana Pensiun Pupuk Kalimantan Timur Tahun 2009-2012)', Sally Febriani, 8(1). Available at: http://administrasibisnis.studentjournal.ub.ac.id/index.php/jab/article/download/349/543.

Hereil, P. et al. (2010) Mutual Fund Ratings and Performance Persistence. Available at: http://www.thierry-roncalli.com/download/lwp-mfr.pdf.

Kristanto., N. H., L.A, A. C. and S., H. B. (2016) 'Implemantasi K-Means Clustering untuk Pengelompokan Analisis Rasio Profitabilitas dalam Working Capital', JUISI, 2(1), pp. 9-15.

Available at: https://journal.uc.ac.id/index.php/JUISI/article/download/111/104.

Kusumadewi, S. (2003) Artificial Intelligence (Teknik dan Aplikasinya). Yogjakarta: Graha Ilmu.

Qiansheng Zhang, Jingru Zhang, Zisheng Chen, Miao Zhang, S. L. (2018) 'A New Stock Selection Model Based on Decision Tree C5.0 Algorithm', Journal of Investment and Management, 7(4), pp. 117-124. doi: 10.11648/j.jim.20180704.12.

Sofariah, A., Saepudin, D. and Umbara, R. F. (2016) 'Menggunakan, Optimasi Portofolio Saham Dengan Memperhitungkan Biaya Transaksi Multi-Objective, Algoritma Genetika', eProceeding of Engineering, 3(1), pp. 1156-1168. Available at: https://openlibrary.telkomuniversity.ac.id/pustaka/files/107490/jurnal_eproc/optimasiportofolio-saham-dengan-memperhitungkan-biaya-transaksi-menggunakan-algoritmagenetika-multi-objective.pdf.

Tandio, T. and Widanaputra, A. A. G. P. (2016) 'PENGARUH PELATIHAN PASAR MODAL, RETURN, PERSEPSI RISIKO, GENDER, DAN KEMAJUAN TEKNOLOGI PADA MINAT INVESTASI MAHASISWA', E-Jurnal Akuntansi Universitas Udayana, 16(3), pp. 23162341. Available at: http://scholar.google.co.id/scholar_url?url=https://ojs.unud.ac.id/index.php/Akuntansi/article/ download/21199/15415\&hl=en\&sa=X\&scisig=AAGBfm1lgRnTtPrSD7vNCJ3_ZXH2UTbapQ \&nossl $=1 \&$ oi $=$ scholarr.

Tiwari, S., Pandit, P. R. and Richhariya, P. V. (2018) 'Predicting future trends in stock market by decision tree rough-set based hybrid system with HHMM', International Journal of Electronics and Computer Science Engineering, 1(3), pp. 1578-1587. Available at: https://pdfs.semanticscholar.org/29a7/e1e1386db50bbb22710d63eb820f9c86ae1b.pdf.

Yusuf, A., Arkeman, Y. and Mushthofa (2012) Pembentukan Portofolio Reksadana Saham yang Optimal Menggunakan Algoritma Genetika Multi Objektif. Bogor. Available at: http://repository.ipb.ac.id/handle/123456789/61367. 